\title{
The Impact of Lockdown on Air Quality in Pakistan during the COVID-19 Pandemic Inferred from the Multi-sensor Remote Sensed Data
}

Special Issue:

Special Issue on COVID-19 Aerosol Drivers, Impacts and Mitigation (XIV)

\section{OPEN ACCESS}

Received: May 15, 2020

Revised: June 6, 2020

Accepted:December 25, 2020

${ }^{*}$ Corresponding Authors: Kanike Raghavendra Kumar kanike.kumar@gmail.com; rkkanike@kluniversity.in Tianliang Zhao

tlzhao@nuist.edu.cn

\section{Publisher:}

Taiwan Association for Aerosol Research

ISSN: $1680-8584$ print

ISSN: 2071-1409 online

(c) Copyright: The Author(s)

This is an open access article distributed under the terms of the Creative Commons Attribution License (CC BY 4.0), which permits unrestricted use, distribution, and reproduction in any medium, provided the original author and source are cited.

\author{
Rehana Khan ${ }^{1,2}$, Kanike Raghavendra Kumar ${ }^{3,1^{*}}$, Tianliang Zhao ${ }^{1^{*}}$ \\ ${ }^{1}$ Collaborative Innovation Centre on Forecast and Evaluation of Meteorological Disasters, Key \\ Laboratory of Meteorological Disaster, Ministry of Education (KLME), International Joint \\ Laboratory on Climate and Environment Change (ILCEC), Key Laboratory for Aerosol-Cloud- \\ Precipitation of China Meteorological Administration, School of Atmospheric Physics, Nanjing \\ University of Information Science and Technology, Nanjing 210044, Jiangsu, China \\ ${ }^{2}$ Department of Physics, Higher Education, Government of Khyber Pakhtunkhwa Peshawar \\ 25000, Pakistan \\ ${ }^{3}$ Department of Physics, Koneru Lakshmaiah Education Foundation (KLEF), Vaddeswaram \\ 522502, Guntur, Andhra Pradesh, India
}

\section{ABSTRACT}

The present study utilized multi-sensory gridded and reanalysis data in conjunction with the meteorological variables to evaluate the impact of lockdown due to the Coronavirus disease of 2019 (COVID-19) pandemic on the changes of concentration of atmospheric pollutants in Pakistan. We focused on assessing the significant changes of pollutant concentrations during March-May for the years 2019 and 2020 utilizing the satellite datasets observed from the Moderate Resolution Imaging Spectroradiometer (MODIS), Ozone Monitoring Instrument (OMI), Atmospheric Infrared Sounder (AIRS), and Modern-Era Retrospective analysis for Research and Applications (MERRA-2) reanalysis data. Low pollution levels were observed throughout the COVID-19 (March 25-May $31,2020)$ compared to a similar period in 2019. The association of meteorology with air pollutants found that the periods of enhanced temperature and relative humidity likely contributed to a cleaner environment over the Indus Basin Region (IBR) and Balochistan Plateau (BP). The decrease in the mean planetary boundary layer Sulphur dioxide $\left(\mathrm{SO}_{2}\right)$ during the lockdown period of 2020 (DLP-2020) was evident by $-36 \%$ in BP, $-34 \%$ in Khyber Pakhtunkhwa (KPK), and $-15.15 \%$ in IBR when compared to before the lockdown period of 2019 (BLP-2019). This is attributed to the limited transportation and control action plans of industrial activities including combustion sources taken by the Government of Pakistan for the DLP-2020 phase. During DLP-2020, a variable and least significant decline in surface particulate matter of size $2.5 \mu \mathrm{m}\left(\mathrm{PM}_{2.5}\right)$ concentration was observed in the urban regions of KPK $(-19.17 \%)$ followed by IBR $(-0.82 \%)$ and BP $(-0.26 \%)$. Overall, a considerable reductions in Carbon monoxide (CO) and black carbon (BC) concentrations were smaller in rural and suburban areas of BP $(-3.61 \%,-8.57 \%)$ followed by KPK $(-0.79 \%,-11.39 \%)$ and IBR $(-3.30 \%,-11.39 \%)$, respectively. This is due to the reduction in local emissions related to the lockdown measures taken in the control of pandemic. However, the ozone $\left(\mathrm{O}_{3}\right)$ concentrations witnessed an increase to a lower extent as $11.39 \%, 5.78 \%$, and $4.74 \%$ in KPK, BP, and IBR, respectively attributed to rising in solar radiation intensity and temperature in hot summers, and decrease in NOx levels during the study period.

Keywords: Air quality, Atmospheric pollutants, COVID-19, Pakistan

\section{INTRODUCTION}

The abrupt outbreak of the Coronavirus disease of 2019 (COVID-19) pandemic produced unprecedented societal impacts over the globe, in particular, the Asia continent, and has drawn 
considerable attention in the recent days and months. Since the detection of the realm's first case in China in late December 2019 and onward in January 2020 in the Asian continent, the concerned Governments of different countries have decided to declare a state of a health emergency. Hence, the regional areas were started locked-down on 23 January 2020, in Wuhan, Hubei province of China, and consequently followed the guidelines given by the World Health Organization (WHO, 2020a, b) to undergo lockdown in other nations. This has been referred to as the largest attempted home quarantine in human history around the world, includes Pakistan (South Asia) with the nation-wide lockdown from 25 March 2020 onwards in different phases. Responding to the ongoing outbreak, the majority of industrial and commercial activities including regional to and from transportation was stopped for about three weeks at an early stage in China. While, the similar sanitary state of emergency was extended to almost all the regions of Asia, which later on spread to the whole world (NASA, 2020).

At the time of completion of writing this manuscript (as of 15 December 2020) a total of 73.99 million cases of COVID-19 had been detected and confirmed across the globe, among which, Pakistan shares more than 0.85 million (World Health Organization., 2020a, 2020b), with 54448 registered cases in Khyber Pakhtunkhwa (KPK) province, 130706 in the Indus Basin Region (IBR), and 17880 COVID-19 positive cases in the Balochistan Plateau (BP). Over the past few years, the fast-growing economy, urbanization, industrial development, and associated growth in emission sources have drawn a huge impact on the air quality of Asian countries including Pakistan (Alam et al., 2012; Khan et al., 2019, 2020), China (Shen et al., 2020; Xu et al., 2020), India (Sharma et al., 2020; Venkat Ratnam et al., 2021) and others. Owing to the pandemic lockdown, regular social activities and the oil/energy consumption of each region has been undoubtedly mitigated emphatically. Several studies over different regions of Asia (Ahmadi et al., 2020; Jahangiri et al., 2020; Kerimray et al., 2020; Sharma et al., 2020; Venkat Ratnam et al., 2021), China (Bao and Zhang, 2020; Muhammad et al., 2020; Shen et al., 2020; Xu et al., 2020), Middle East (Broomandi et al., 2020; Faridi et al., 2020), Europe (Bauwens et al., 2020; Martínez et al., 2020; Nakada et al., 2020; Siciliano et al., 2020; Tobías et al., 2020; Sannino et al., 2021), and USA (Bauwens et al., 2020; Berman and Ebisu, 2020; CDC, 2020) had examined and documented the significant role of regional lockdown on air quality by using the ground- and space-based sensors. However, it is still needed to assess the atmospheric pollution influence during the regional lockdown in different domains of Asia, including Pakistan to reveal its implication for pollution control strategies. The NASA satellite images clearly showed that the concentrations of trace gases dropped drastically (30-40\%) in February over Wuhan (NASA, 2020; Wang et al., 2020). Both the air precursors will improve the air quality on a local and regional basis ((Bao and Zhang, 2020).

According to the investigation of the NASA scientists (NASA, 2020), the pollutant levels (such as Carbon monoxide ( $\mathrm{CO})$, Carbon dioxide $\left(\mathrm{CO}_{2}\right)$, and Black Carbon $(\mathrm{BC})$ ) in the air is decreased significantly by $-30 \%$ for the trace gases, and $-25 \%$ for $\mathrm{CO}_{2}$ in central $\mathrm{China}$, and $-6 \%$ in the world (Carbon Brief, 2020) after the first lockdown in China. Further, a decrease in pollutant levels over North China was found by an average of $-13.71 \%,-5.91 \%,-6.82 \%$, and $-4.60 \%$, for particulate matter with the aerodynamic size of $10 \mu \mathrm{m}$ and $2.5 \mu \mathrm{m}\left(\mathrm{PM}_{10}\right.$ and $\left.\mathrm{PM}_{2.5}\right)$, Sulphur dioxide $\left(\mathrm{SO}_{2}\right)$, and carbon monoxide (CO) over 44 different cities reported by Bao and Zhang (2020) using the remote sensing data. However, in another work conducted in India, the decrease in $\mathrm{PM}_{2.5}$ concentration was found the highest (-50\%) over New Delhi (India) out of several major cities in the Asian continent during the COVID-19 lockdown period (Mahato et al., 2020). Later on, by using the same resources (remote sensing data), a significant decline in the concentrations of basic air pollutants $\mathrm{PM}_{10}(43 \%), \mathrm{PM}_{2.5}(31 \%), \mathrm{NO}_{2}(18 \%)$, and $\mathrm{CO}(10 \%)$ was observed over 22 major cities of India during the first phase of lockdown period (26 March-14 April 2020) (Sharma et al., 2020). Moreover, they have reported that the surface ozone $\left(\mathrm{O}_{3}\right)$ levels are gradually exceeded in almost all the study sites in India ranging from $5 \%$ to $22.5 \%$. Further, Panda et al. (2020) and Chauhan and Singh (2020) found a decrease in $\mathrm{PM}_{10}(60 \%), \mathrm{PM}_{2.5}(36 \%)$, and $\mathrm{CO}(30.4 \%)$ concentrations using the in situ measurements in India for the study period (January-February 2020).

A similar decrease is also seen in other trace gases resulted in the improvement of regional air quality over many countries that remain under lockdown. Using the ground- and satellite-based measurements, a striking reduction in air pollutants $\mathrm{SO}_{2}, \mathrm{CO}$, and $\mathrm{PM}_{2.5}$ have been observed over India $(-17.97 \%,-10 \%$, and $-43 \%)$, Barcelona $(-19.4 \%,-28 \%)$, Germany, Belgium (-20\%), and U.S.A (-20 to 38\%) (Bauwens et al., 2020; Dantas et al., 2020; Li et al., 2020; Panda et al., 2020; 
Tobías et al., 2020). However, in Western Europe (Rome and Turin), the reduction in some pollutants $\left(\mathrm{PM}_{2.5}\right.$ and $\left.\mathrm{PM}_{10}\right)$ was recorded to be relatively lower $(-10.21 \%)$. All these studies have examined and documented the significant role of regional lockdown on air quality by using ground and space-borne observations. However, it is needed to assess the atmospheric impacts of pandemic outbreaks in the unexplored South Asia region, particularly in Pakistan to reveal its implication for pollution control strategies. Hence, the present work elucidates the effectiveness of present lockdown measures on the air quality in different regions of Pakistan, namely Khyber Pakhtunkhwa (KPK), Indus Basin Region (IBR), and Balochistan Plateau (BP). In this regard, the space-borne satellites (Moderate Resolution Imaging Spectroradiometer (MODIS), Ozone Monitoring Instrument (OMI), and Atmospheric Infrared Sounder (AIRS) and Modern-Era Retrospective analysis for Research and Applications of version 2.0 (MERRA-2) reanalysis model data set have been executed on the selected regions located in the study domain to ascertain the significant aftermath of Before Pandemic Lockdown Period (BLP) and During pandemic Lockdown Periods (DLP) of COVID-19. In this study, we have analyzed the spatiotemporal distributions of precursor gases $\left(\mathrm{SO}_{2}, \mathrm{CO}, \mathrm{O}_{3}\right), \mathrm{BC}, \mathrm{PM}_{2.5}$, and column aerosol optical thickness (AOT) to interpret and understand the reasons behind the significant changes in regional air quality under the lockdown period in Pakistan.

\section{STUDY DOMAIN}

The present study evaluates the variations of main atmospheric pollutants concentrations over Pakistan (latitude from $24^{\circ}$ to $37^{\circ} \mathrm{N}$, and longitude between $62^{\circ}$ and $75^{\circ} \mathrm{E}$ ). The mainland is presented with high topographical heterogeneity (see Fig. 1), varying aerosol emission sources, and distinct meteorological properties. The area is marked by large variations in temperature across different seasons, with a mean from $2.3^{\circ} \mathrm{C}$ in winter to about $36^{\circ} \mathrm{C}$ in summer. The rapidly expanding urbanization, industrial/agricultural activities, and energy utilization resulted in increasing amounts of anthropogenic emissions and, in turn, deterioration of air quality (Alam et al., 2012). In the present study, to analyze the impact of COVID-19 pandemic lockdown on the air

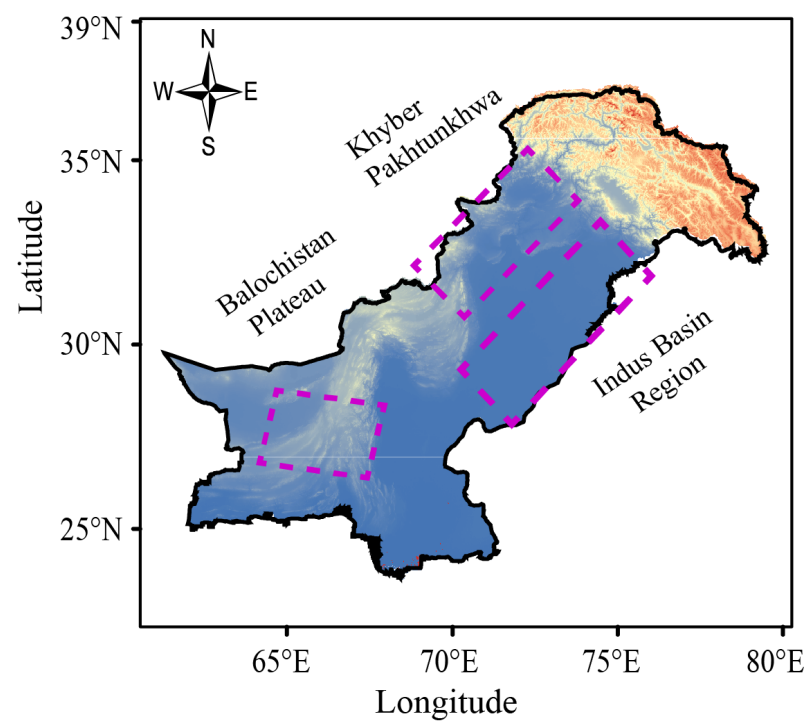

Legend
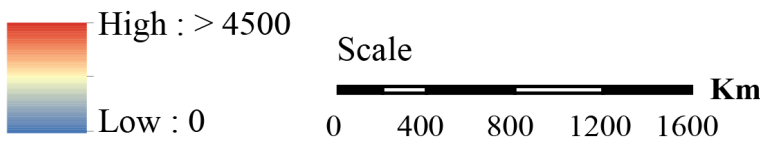

Fig. 1. Topographic map of Pakistan with a color scale presented at bottom left to the figure. The areas enclosed in pink box represent major regions considered in the present study from the entire domain. 
quality, the study domain (Pakistan) is divided into three major regions as Khyber Pakhtunkhwa (KPK), Indus Basin Region (IBR), and Balochistan Plateau (BP). The KPK region is one of the urban and populated regions of the country, bounded by the greater Himalayan mountain range on one side, which acts as a barrier, trapping the aerosols and air pollutants over the region. The IBR has the highest population density in Pakistan and is characterized by large emission sources and pollutants including desert dust and anthropogenic aerosols from the industrial sectors. The BP region is mostly known for high elevation mountainous regions and reflects the semi-urban and rural environment of the study domain, where anthropogenic activities are observed less compared to the rest of the study areas (Zhang et al., 2020). However, being the land lock region, the air pollutants mostly staying for a longer period, throughout the year in this region. In recent years, with the increase in population, rapid urbanization in most of the areas resulted in an enhanced amount of the consumption of fossil fuel in the energy production sectors, while the biomass burning in the rural areas has to lead to high aerosol loading over Pakistan (Alam et al., 2012).

\subsection{Satellite and Reanalysis Data}

The data used in this study are observed from three Earth Observation System (EOS) satellites namely, Moderate-resolution Imaging Spectroradiometer (MODIS), Atmospheric Infrared Sounder (AIRS), and Ozone Monitoring Instrument (OMI), and also the MERRA-2 reanalysis model data for the study period. The datasets from the above sensors were downloaded for a period of a total of 68 days ( $~ 9$ weeks) Before- and During- the Lockdown periods labeled as BLP-2019 (March 25May 31, 2019) and DLP-2020 (March 25-May 31, 2020), respectively. The retrieved satellite data were further processed using different computational tools such as GEE (Google Earth Engine), CCP (Cloud Computing Platform), Arc GIS, and MatLab probably the best proposition to understand the changes in air pollutants; and to evaluate the impact of lockdown on regional air quality over the study domain.

\subsubsection{The AIRS sensor}

The AIRS launched on 4 May 2002 (onboard NASA's Aqua platform) is capable to globally monitor the tropospheric $\mathrm{CO}$ mole fraction (in ppbv; parts per billion volume) in the air (Chahine et al., 2005). The AIRS cross-track scanning grating spectrometer offers atmospheric vertical profiles with a field of view of $45 \mathrm{~km}$ nadir through $1650 \mathrm{~km}$ swath (Aumann et al., 2003). The sensor provides broad spectral coverage in the range of 3.75 to $15.4 \mu \mathrm{m}$ with 2378 different channels. Further, the AIRS enable $70 \%$ of the global retrieval twice per day, nearly in both hemispheres with an angle range of $45^{\circ}-80^{\circ}$. The AIRS data sets are validated using the ground-based total column CO observations measured in Russia and Australia; and agreement between AIRS and airborne measurements were found within an average of 10-15 ppbv (Yurganov et al., 2008). This agreement between the space-borne AIRS and ground-based total column measurements (CO) (not shown here) enables us to use AIRS in the present work to investigate the spatial and temporal levels of CO for the phases of BLP-2019 and DLP-2020.

\subsubsection{The MODIS sensor}

The global imaging sensor MODIS has been flying aboard the Terra and Aqua satellites (which is an important part of NASA's EOS), since May 2000 and July 2002, respectively. It provides several aerosol products over the ocean and land (Kaufman et al., 1997). The sensor measures radiances at spatial resolutions of $0.25,0.5$, and $1.0 \mathrm{~km}$, depending mainly on the waveband. The aerosol products derived from MODIS have proven to be reliable over oceans, dark and bright land surfaces after recent improvements in the aerosol retrieval algorithms (Sayer et al., 2013). Over dark surfaces (vegetative land and oceans), AOT is retrieved using the Dark-Target (DT) algorithm (Kaufman et al., 1997). However, the Deep Blue (DB) algorithm is used for bright surfaces (Hsu et al., 2004). The complete details about DT and DB algorithms can be found in Levy et al. (2013). In this study, daily mean AOT is obtained from archived MODIS recent Collection 6.1 (MOD08) Level 3 Aqua (merged DT and DB) dataset. The Level 3 product is the new version of MODIS Level 2 with the best quality assurance (QA) flag (value-3) and is available at spatial resolution of $1^{\circ} \times 1^{\circ}$ (Kaufman et al., 1997). The QA data files are extracted using the HDF view tool. The radiometric calibration and orbit stability both are rigorously maintained by the MODIS 
Characterization Support Team (MCST), to within $\pm 2-3 \%$ at specific situations (Remer et al., 2005). Also, through this QA/QC Check, data quality and uniformity have improved substantially over the last couple of years. However, Global validation exercises have indicated expected uncertainties for $\mathrm{AOT}_{550}$ as $\pm(0.05 \times \mathrm{AOT}+0.03)$ and $\pm(0.15 \times \mathrm{AOT}+0.05)$ over ocean and land, respectively (Kaufman et al., 1997; Remer et al., 2005).

\subsubsection{The OMI sensor}

The OMI Aura is a nadir-viewing spectrometer onboard NASA's Aura satellite and is the first sensor capable of working on UV and visible spectrum with a charge-coupled device, enabling daily global monitoring of $\mathrm{O}_{3}, \mathrm{NO}_{2}$, and $\mathrm{SO}_{2}$ concentrations (Levelt et al., 2006). In addition to AIRS and MODIS, OMI Aura derived daily total column $\mathrm{O}_{3}$ and $\mathrm{SO}_{2}$ observed in the planetary boundary layer (PBL) were analyzed in the present work. The OMI sensor utilizes two algorithms for retrieving aerosol information from the measurements of TOA reflectance: i) the OMAERUV aerosol product (near-UV algorithm) and ii) OMAERO aerosol product (multi-wavelength algorithm) (Torres et al., 1998). The precision uncertainty for the derived gridded $\mathrm{O}_{3}$ is 5 Dobson Unit (DU) with a mean offset of $2 \mathrm{DU}$ (OMI/MLS) (Ziemke et al., 2009). Column amount $\mathrm{SO}_{2}$ in the PBL has an uncertainty of 0.5-0.9 DU (Theys et al., 2015). The discrepancies are even smaller on a regional scale and when considering individual sectors. Further, the $\mathrm{OMI}$ retrieved $\mathrm{O}_{3}$ and $\mathrm{SO}_{2}$ data are available from the NASA GES DISC at http://disc.gsfc.nasa/gov/.

\subsubsection{The MERRA-2 reanalysis data}

The Modern-Era Retrospective analysis for Research and Applications (MERRA-2) is a global modeling-GMAO product sponsored by NASA and is capable of providing a regularly gridded and homogeneous data set of the atmosphere from 1980 to the present. The model uses the new version of the GEOS-5 (Goddard Earth Observing System Model, version 5) data assimilation system to synthesize regular time series of gridded data, with a spatial resolution of $0.5^{\circ} \times 0.625^{\circ}$ at 72 pressure levels (from the surface to $0.01 \mathrm{hPa}$ ) with both instantaneous and time-averaged (hour, 3-hours, and month). Among the advantages of MERRA-2, in comparison with its previous version, are an improved presentation of the hydrological cycle, cryosphere-stratosphere processes, atmospheric ozone, as well as joint assimilation of aerosol and meteorological fields, accounting for their interaction through the radiative effects of atmospheric aerosol (Gelaro et al., 2017). However, the aerosol assimilation system in MERRA-2 uses AOT measurements from satellite instruments (such as MODIS, MISR, AVHHR) and also from the ground-based Aerosol Robotic Network (AERONET) stations. The MERRA-2 surface mass concentration of hourly BC and column mass density of $\mathrm{PM}_{2.5}$ were analyzed in the present work, which is in open access and free for the public (https://disc.sci.gsfc.nasa.gov/). Till now, the uncertainty in MERRA-2 derived $\mathrm{PM}_{2.5}$ (compared to ground data set) is revealed as 19.2-23.6\% in Asia (China) (Ma et al., 2020a). The underestimations in PM 2.5 concentration by MERRA- 2 is affiliated mainly with the uncertainty in the magnitude of the emission inventory used in the comparison model. An overview of the MERRA-2 modeling system and a more detailed description of aerosols in the MERRA-2 database can be found in Buchard et al. (2017), Gelaro et al. (2017), and Randles et al. (2017).

\section{RESULTS}

\subsection{Changes in Aerosol and Trace Gases Concentrations}

In this study, we used the column AOT from the MODIS-Aqua satellite, CO mole fraction from the AIRS sensor, $\mathrm{SO}_{2}$ in the $\mathrm{PBL}$ and total column $\mathrm{O}_{3}$ from the $\mathrm{OMI}$ satellite along with the mass concentrations of $\mathrm{PM}_{2.5}$ and $\mathrm{BC}$ from the MERRA-2 reanalysis model observed over three different regions (KPK, IBR, and $\mathrm{BP}$ ) in Pakistan. It is taken to measure the variations of atmospheric pollutant concentrations because of the general nation-wide COVID-19 lockdown in Pakistan. We first analyzed the satellite-derived estimates of averaged $\mathrm{AOT}, \mathrm{PM}_{2.5}, \mathrm{SO}_{2}, \mathrm{CO}, \mathrm{BC}$, and $\mathrm{O}_{3}$ concentrations across the selected regions of interest for the BLP-2019 and DLP-2020 (Figs. 2, 3, and Table 1). The MODIS-Aqua satellite and MERRA-2 reanalysis model estimates showed a significant decline in column AOT and surface $\mathrm{PM}_{2.5}$ by $-0.02(-9.09 \%)$ and $-3.7 \mu \mathrm{g} \mathrm{m}^{-3}(-19.17 \%)$ across KPK, $-0.02(-4.34 \%)$ and $-0.3 \mu \mathrm{g} \mathrm{m}^{-3}(-0.82 \%)$ in the IBR, and $-0.01(-2.9 \%)$ and $-0.1 \mu \mathrm{g} \mathrm{m}^{-3}(-0.26 \%)$, 
BLP-2019
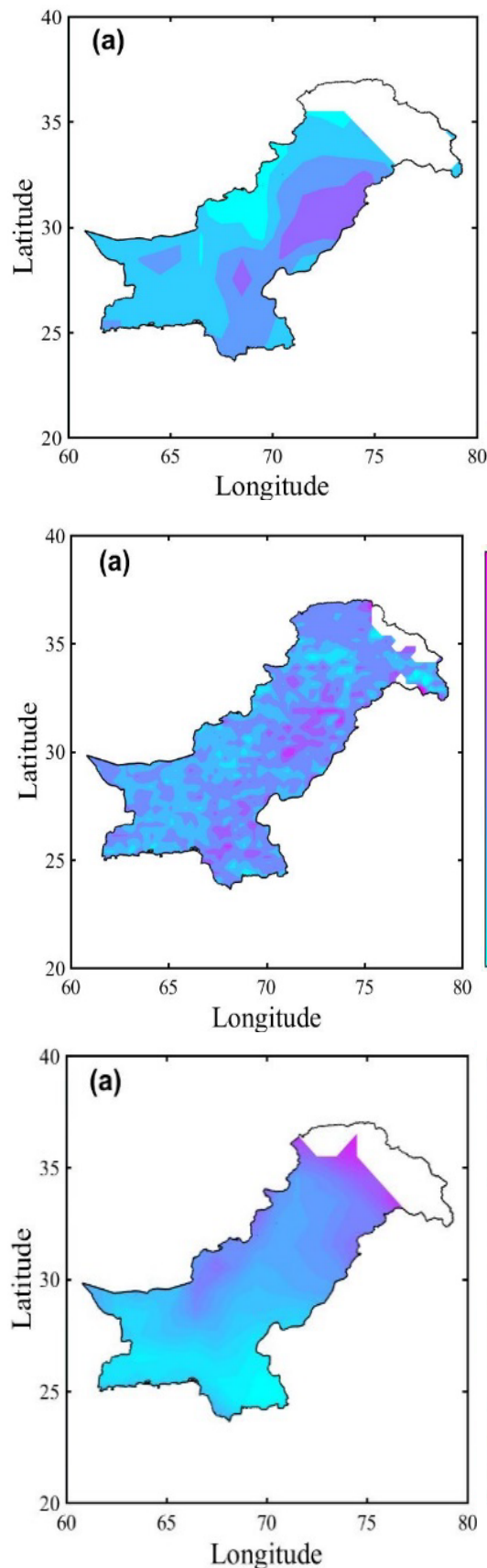

DLP-2020
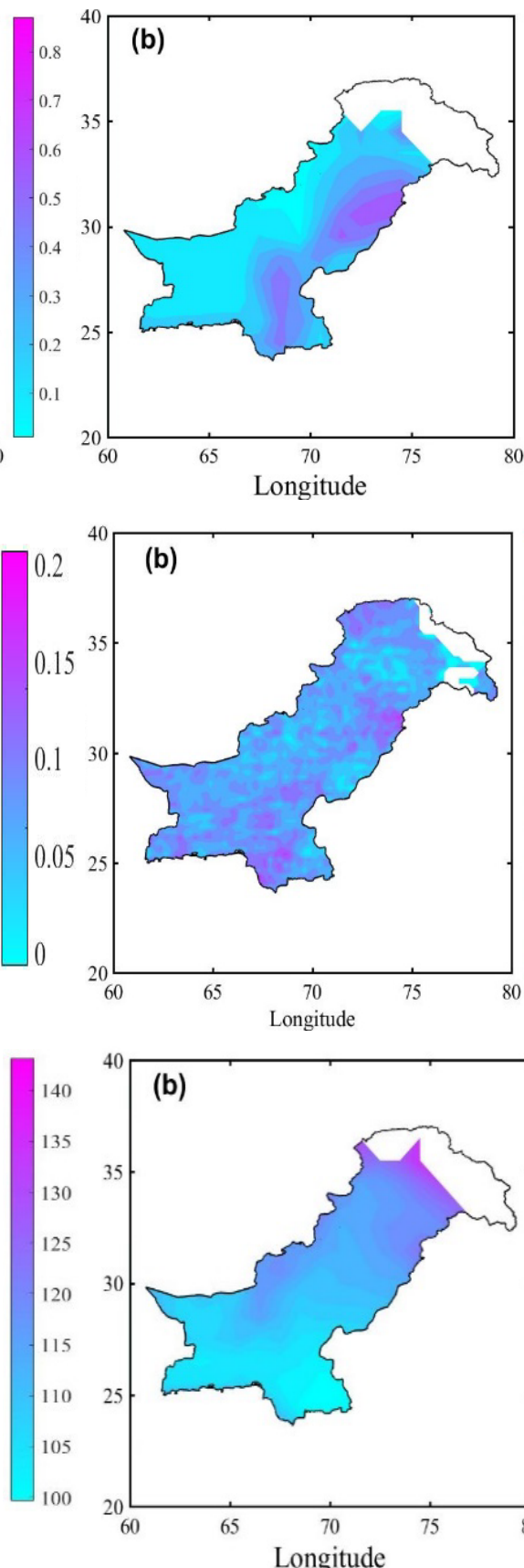
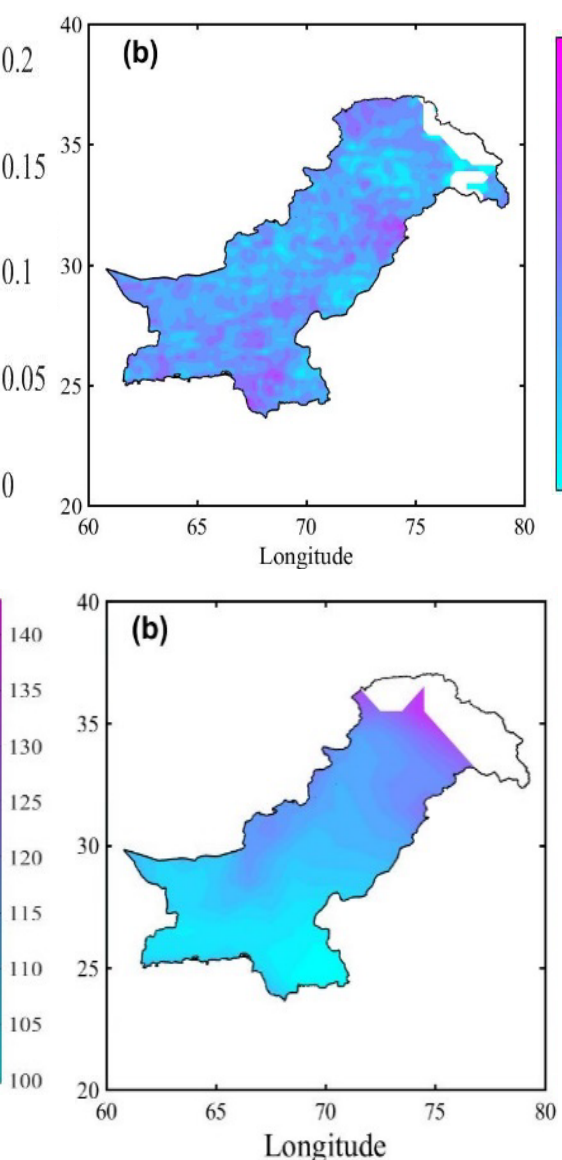

DIFF (\%)
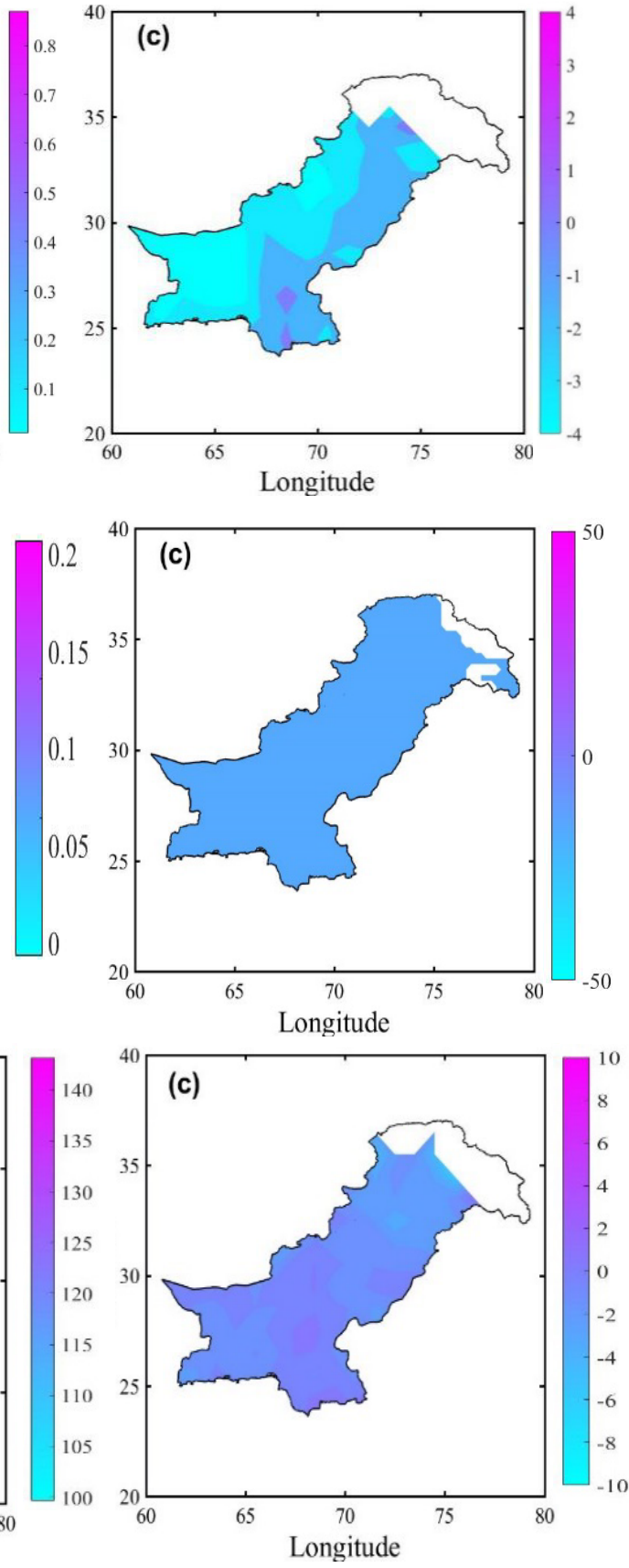

Fig. 2. Changes in columnar $\mathrm{AOT}_{550}$ retrieved from the MODIS-Aqua (upper panels); column amount of $\mathrm{SO}_{2}$ in the PBL from $\mathrm{OMI}$ (middle panels); and mole fraction of $\mathrm{CO}$ in air from AIRS (bottom panels) around Khyber Pakhtunkhwa, Indus Basin Region, and Balochistan Plateau: (a) Before-(BLP-2019), (b) During-(DLP-2020) the lockdown period, and (c) the fractional change (\% difference) between (a) and (b) calculated in unit of ppbv (CO); $\mathrm{DU}\left(\mathrm{SO}_{2}\right)$; and AOT (unit less). 1 Dobson Unit (DB) $=0.4462 \mathrm{mmol} \mathrm{m}^{-2}$ and ppbv $=$ parts-per billion volume.

respectively in the $\mathrm{BP}$ region during the study period influenced by the traffic emission and biogenic sources in addition to the contribution from the anthropogenic sources (Alam et al., 2012).

The $\mathrm{CO}$ concentrations were also found lower during the DLP-2020 in comparison to last year (PLP-2019) for the BP region $-3.98(-3.61 \%)$ ppbv followed by IBR with $-3.92(-3.30 \%)$ ppbv. No significant lower values of concentrations were recorded for KPK $-0.94(-0.79 \%)$ ppbv during the study period (Fig. 2, Table1). The decrease in CO levels is likely related to the temporary augmented control in local/regional pollution activities during the lockdown period. On the contrary, a more 
BLP-2019
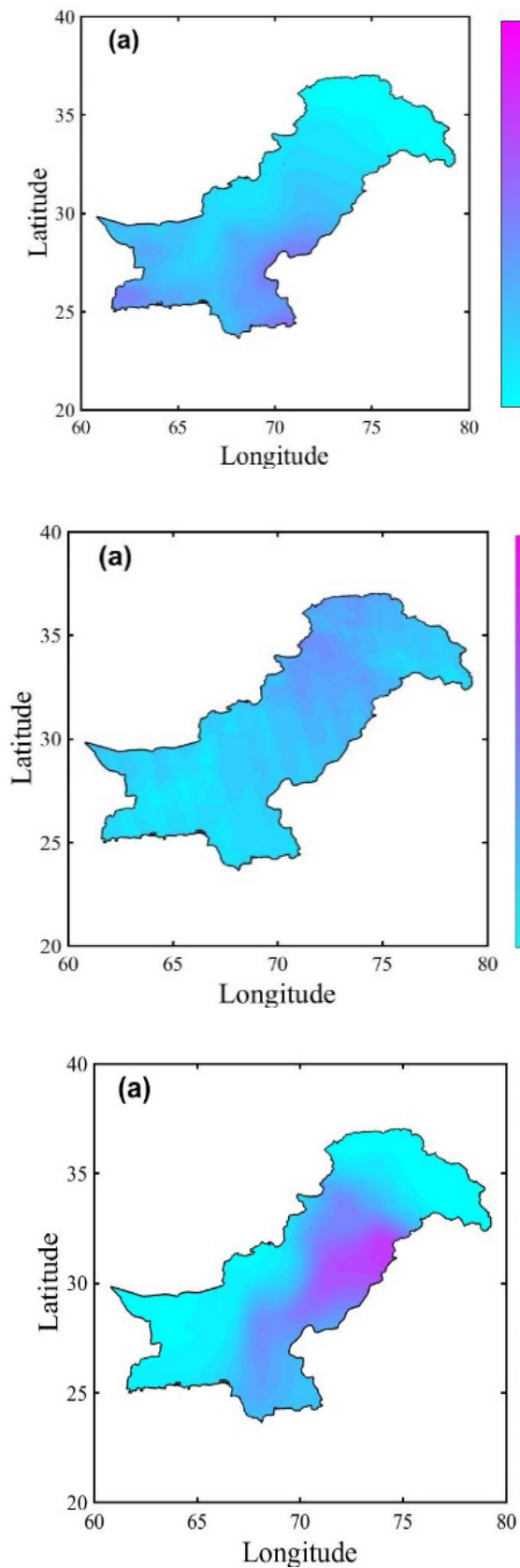

DLP-2020
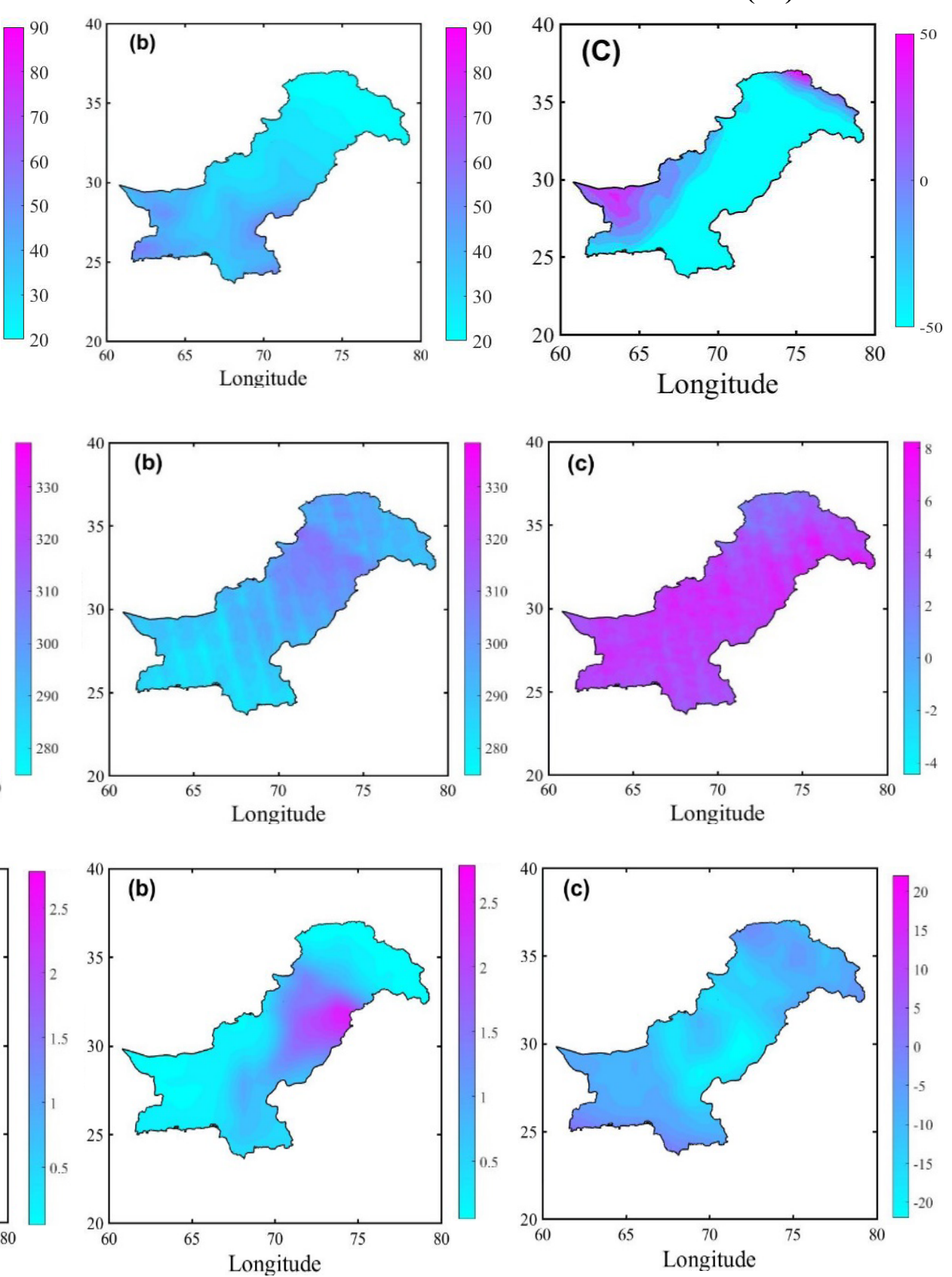

Fig. 3. Same as in Fig. 2, but for the $\mathrm{PM}_{2.5}$ (upper panels), $\mathrm{O}_{3}$ from the $\mathrm{OMI}$ (middle panels), and mass concentration of $\mathrm{BC}$ (bottom panels) from MERRA-2 for the study period.

pronounced decline in $\mathrm{SO}_{2}$ was found as $-36 \%$ for $\mathrm{BP}$ followed by KPK (-34\%) and comparatively lower for IBR (-15.15\%). The same is attributed to the alteration of basic source activities, primarily associated with the restriction of transportation and controlled industrial activities. Further, the gradual increase in $\mathrm{O}_{3}$ concentrations is visible clearly from the spatial plot (Fig. 3(b), Table 1) during the DLP-2020, with a mean $( \pm S D)$ and gradual percent increase of $287.79 \pm 13.57$ DU and $5.78 \%$ in the BP region followed by the IBR with $300.65 \pm 14.66 \mathrm{DU}$ and $4.63 \%$, and KPK with $304.32 \pm 19.38 \mathrm{DU}$ and a comparatively lower increase in $\mathrm{O}_{3}$ of $4.05 \%$. The gradual increase in $\mathrm{O}_{3}$ is associated with the decreasing shift in primary pollutant $\mathrm{NO}_{\mathrm{x}}$ and $\mathrm{PM}_{\mathrm{x}}(\mathrm{x}=2.5$ or $10 \mu \mathrm{m})$ generated from the urbanized and industrialized areas of Pakistan. Another potential reason is the insolation and temperature shift from spring to summer in the northern hemisphere led to an increase in $\mathrm{O}_{3}$ (Mahato et al., 2020). 
Table 1. Basic statistics pertaining to $24 \mathrm{~h}$ mean $( \pm S D)$ concentrations of $A \mathrm{OT}_{550}, \mathrm{PM}_{2.5}, \mathrm{BC}$, and trace gas pollutants $\left(\mathrm{SO}_{2}, \mathrm{CO}, \mathrm{O}_{3}\right.$ and $\mathrm{NO}_{2}$ ) for the period between March 25 to May 31, 2020 (during the lockdown period (DLP-2020) and before the lockdown period (BLP-2019)) for the three major study regions Khyber Pakhtukhwa, Upper Indus Basin and Balochistan Plateau in Pakistan. The Difference of two different data periods with its percentage values is also presented.

\begin{tabular}{|c|c|c|c|c|c|}
\hline Study Site & Air Pollutant (Unit) & BLP-2019 & DLP-2020 & Difference & $\%$ Variation \\
\hline \multirow[t]{6}{*}{ Khyber Pakhtunkhwa } & $\mathrm{AOT}_{550}$ & $0.22 \pm 0.03$ & $0.19 \pm 0.04$ & -0.02 & -9.09 \\
\hline & $\mathrm{PM}_{2.5}\left(\mu \mathrm{g} \mathrm{m}^{-3}\right)$ & $29.3 \pm 2.4$ & $25.6 \pm 3.9$ & -3.7 & -19.17 \\
\hline & $\mathrm{SO}_{2}(\mathrm{DU})$ & $0.05 \pm 0.06$ & $0.033 \pm 0.065$ & -0.017 & -34 \\
\hline & CO (ppbv) & $119.55 \pm 1.13$ & $118.60 \pm 0.54$ & -0.94 & -0.79 \\
\hline & $\mathrm{O}_{3}(\mathrm{DU})$ & $292.23 \pm 13.42$ & $304.32 \pm 19.38$ & 12.08 & 4.13 \\
\hline & $\mathrm{BC}\left(\mu \mathrm{g} \mathrm{m}^{-3}\right)$ & $0.79 \pm 0.16$ & $0.74 \pm 0.1$ & -0.09 & -11.39 \\
\hline \multirow[t]{6}{*}{ Upper Indus basin } & $\mathrm{AOT}_{550}$ & $0.46 \pm 0.9$ & $0.44 \pm 0.00$ & -0.02 & -4.34 \\
\hline & $\mathrm{PM}_{2.5}\left(\mu \mathrm{g} \mathrm{m}^{-3}\right)$ & $36.7 \pm 10.1$ & $36.4 \pm 1.4$ & -0.3 & -0.82 \\
\hline & $\mathrm{SO}_{2}(\mathrm{DU})$ & $0.066 \pm 0.065$ & $0.055 \pm 0.03$ & -0.01 & -15.15 \\
\hline & CO (ppbv) & $118.71 \pm 4.41$ & $114.79 \pm 4.2$ & -3.92 & -3.3 \\
\hline & $\mathrm{O}_{3}(\mathrm{DU})$ & $287.04 \pm 13.48$ & $300.65 \pm 14.66$ & 13.61 & 4.74 \\
\hline & $\mathrm{BC}\left(\mu \mathrm{g} \mathrm{m}^{-3}\right)$ & $1.56 \pm 0.19$ & $1.21 \pm 0.17$ & -0.35 & -22.43 \\
\hline \multirow[t]{6}{*}{ Balochistan Plateau } & $\mathrm{AOT}_{550}$ & $0.35 \pm 0.01$ & $0.34 \pm 0.03$ & -0.01 & -2.9 \\
\hline & $\mathrm{PM}_{2.5}\left(\mu \mathrm{g} \mathrm{m}^{-3}\right)$ & $38.8 \pm 2.5$ & $38.7 \pm 4.2$ & -0.1 & -0.26 \\
\hline & $\mathrm{SO}_{2}(\mathrm{DU})$ & $0.05 \pm 0.06$ & $0.032 \pm 0.06$ & -0.018 & -36 \\
\hline & CO (ppbv) & $110.06 \pm 1.85$ & $106.08 \pm 2.54$ & -3.98 & -3.61 \\
\hline & $\mathrm{O}_{3}(\mathrm{DU})$ & $272.05 \pm 11.73$ & $287.79 \pm 13.57$ & 15.74 & 5.78 \\
\hline & $\mathrm{BC}\left(\mu \mathrm{g} \mathrm{m}^{-3}\right)$ & $0.35 \pm 0.10$ & $0.31 \pm 0.06$ & -0.03 & -8.57 \\
\hline
\end{tabular}

The magnitude of decrease in BC, for the suburban and industrial background regions of IBR and KPK, was found higher (-22.43\% and $-11.39 \%)$ with a mean difference of $-0.35 \mu \mathrm{g} \mathrm{m}^{-3}$ and $-0.03 \mu \mathrm{g} \mathrm{m}^{-3}$, respectively. Notable reductions are also seen in industrial, suburban, and rural sites across the country (Fig. 3). However, $\mathrm{PM}_{2.5}$ concentration has counted the least in comparison to other air pollutants for almost all the study areas. It is known that $\mathrm{PM}_{2.5}$ aerosols are mainly associated with the combustion of coal and natural gas, power plants, industries, and automobiles. Indeed, the lockdown measures reduced the outdoor emission activities but on the other hand, it was replaced by the indoor domestic heating and relevant biomass burning resources at the same time in DLP-2020. The reason behind this is the sources (particles from residential energy, agriculture sector, including desert dust) affiliated with the emission of $\mathrm{PM}_{\mathrm{x}}$, which were observed partially active in the study areas. Further, the meteorological parameters such as precipitation, relative humidity, and wind speed are also considered to be active parameters in this domain that might be interlinked with the preset results (Khan et al., 2020).

Overall, the study domain (Pakistan) showed a more substantial decrement in the surface mass concentration of BC in the DLP-2020, with the mean statistical variance (\% Diff) of -0.10 ( $-13 \%$ ) $\mu \mathrm{g} \mathrm{m}^{-3}$ followed by $\mathrm{PM}_{2.5}$ with $-2.25(-7.39 \%) \mu \mathrm{g} \mathrm{m}^{-3}, \mathrm{SO}_{2}$ with $-0.01(-2.24 \%) \mathrm{DU}$ and $\mathrm{CO}-5.55$ $(-4.76 \%)$ ppbv in comparison to the last year (Figs. 2, 3, and 4). Since, the air pollutants such as Nitrates and Sulfates are emitted from the urban and industrial areas by transportation units, thermal power plants, and other industrial activities. While the carbon-rich soot and $\mathrm{PM}_{\mathrm{x}}$ are being produced by the burning of coal and wood, and consumption of fossil fuel. The burning of agricultural residues after harvest and charcoal used for cooking in the rural areas of BP produces smoke that contains black or organic carbon (although agricultural burning or biomass burning occurs more regularly) during this period every year (Mayol-Bracero et al., 2002). The shift in AOT was observed overall with the mean statistical variance (\% Diff) of $-0.03(-9.8 \%)$, and an increase in $\mathrm{O}_{3}$ was noticed as $13.96 \mathrm{DU}(4.83 \% \mathrm{DU})$ in Pakistan.

\subsection{Role of Meteorology}

The regional meteorology produces a unique experiment to assess the efficiency of air pollution diminution during the COVID-19 Pandemic period in Pakistan. Since meteorology always played an important role in the formation and transport of air pollutants in both urban and rural atmospheres 

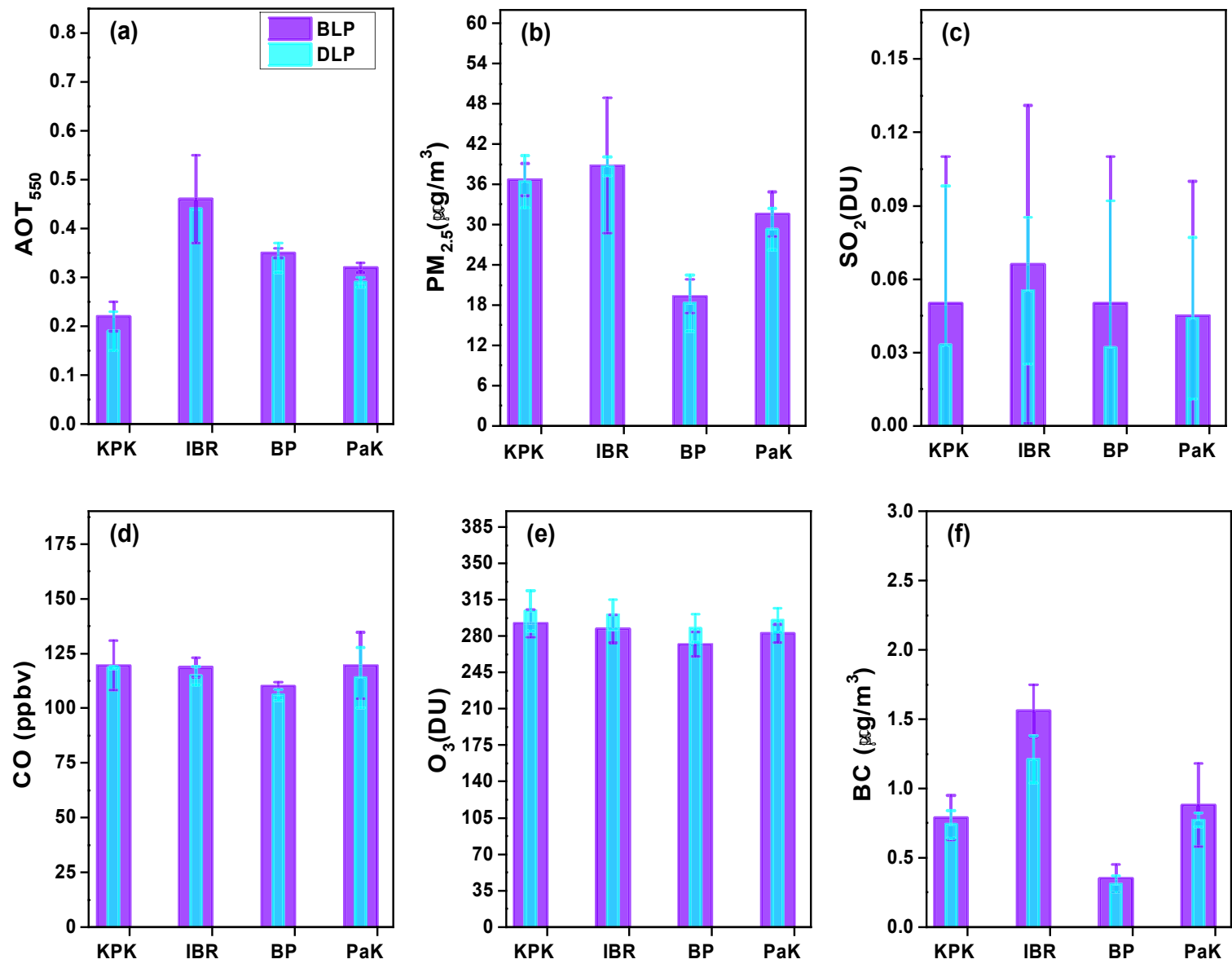

Fig. 4. Histogram maps presenting the averaged $A O T_{550}, \mathrm{PM}_{2.5}$, and precursor gases $\left(\mathrm{CO}, \mathrm{BC}, \mathrm{SO}_{2}, \mathrm{O}_{3}\right)$ concentrations observed from the MODIS-Aqua, MERRA-2, AIRS and OMI retrievals, respectively over industrial, urban, sub-urban and rural sites in Pakistan before and during the pandemic period 25 March-31 May for the years 2019 and 2020. Vertical bars correspond to one sigma standard deviation of the mean.

(Albrecht et al., 1989; Lelieveld and Heintzenberg, 1992). We compared briefly, the meteorological parameters such as temperature (in K) and relative humidity (in \%) with the aerosol and trace gas concentrations during DLP-2020 over the study areas (Figs. 5-7) in Pakistan.

Temperature is one of the key influencing factors for air pollutant concentrations across Pakistan (Khan et al., 2019). Our observation shows an increase (decrease) in temperature (RH), (Figs. 5(a)-7(a)) for the DLP-2020 phase. The temperature rise is usually expected during these days (March-May) of the year in the study region (Alam et al., 2012). Throughout the DLP-2020, the gradual increase in temperature is observed with noticeable periodic alteration in $\mathrm{RH}$ over the study areas, with maximum T (304K) in UIP followed by BP with $300 \mathrm{~K}$ and $299 \mathrm{~K}$ over the KPK region and lower $\mathrm{RH}$ values of $30 \%, 20 \%$, and $37 \%$, respectively. The most notable variation occurred over KPK, where the temperature dropped down almost three times with a visible difference of (274-296 K) during the first phase of DLP-2020 (Figs. 5(a)-5(f)) with an increase in RH. These results could promote reductions in aerosols. A gradual decline in $\mathrm{AOT}, \mathrm{CO}, \mathrm{BC}$, and $\mathrm{SO}_{2}$ during lockdown can also be seen in the temporal evaluation (Figs. 5-7). Results clearly show that a sharp decline in both AOT and $\mathrm{PM}_{2.5}$ values is observed during the first week of lockdown; however, after some time, (during the last week of DLP-2020) a sudden increment in both the parameters is noticed attributed to the end of lockdown phase and the regain in anthropogenic activities associated with the restoration of social and commercial pursuits and increase in temperature (Gunthe et al., 2020; Ma et al., 2020b). Since, relative humidity (RH) plays an effective role in the hygroscopic growth of atmospheric pollutants (Carrico et al., 2003; Kumar et al., 2013; Ahlawat et al., 2020). Under humid conditions, the air pollutant exhibited a linear decrease with the temperature in the study regions (Figs. 5-7). In general, high temperature favors more air pollutants 

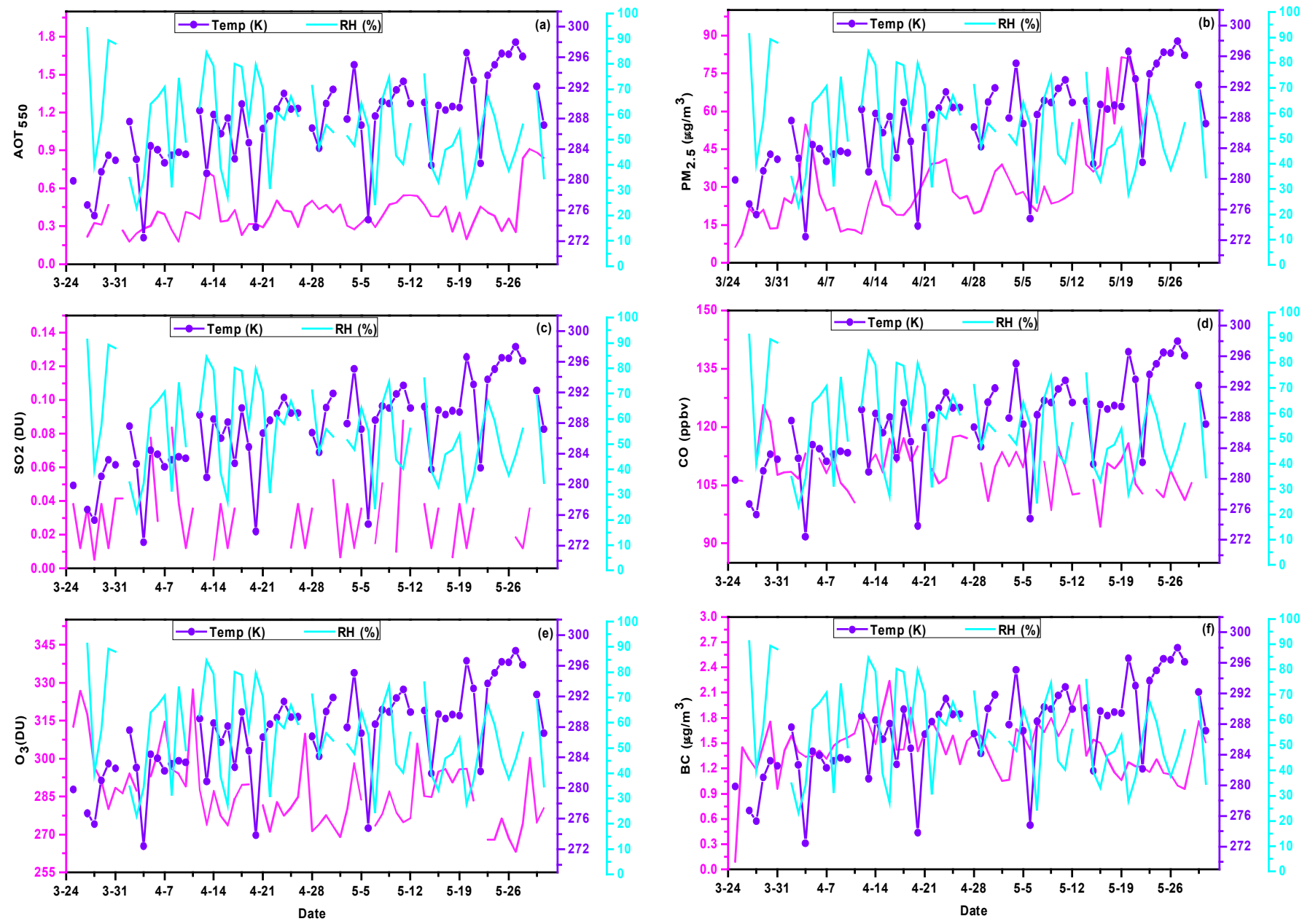

Fig. 5. Variations of daily averaged temperature, relative humidity (RH) with (a) $A_{0} T_{550}$, (b) Dust surface mass concentration of $\mathrm{PM}_{2.5}$, (c) Planetary Boundary Layer $\mathrm{SO}_{2}$ column amount, (d) Mole fraction of $\mathrm{CO}$, (e) total column amount of $\mathrm{O}_{3}$, and (f) $\mathrm{BC}$ surface mass concentration in Khyber Pakhtunkhwa during March-May 2020.

to dispersion in a dry/less humid atmosphere and results in a lower concentration of aerosols. Results indicate that temperature is likely to have a substantial effect on the variations of atmospheric pollutant concentrations. It is predicted that a $10^{\circ} \mathrm{C}$ decrease in temperature would increase air pollutant yields by $20-150 \%$, in presence of a humid atmosphere (Bowman et al., 2001).

Total column ozone $\left(\mathrm{O}_{3}\right)$ concentrations typically experience a cycle opposite that of other trace gases, with peak levels at mid of the DLP-2020 in all study areas (Figs. 5-7). This is attributed to the result of a gradual decline in $\mathrm{NO}_{3}$ (Table 1 ) and the potential increase in temperature beside the dry atmosphere. The daily mean column amounts of $\mathrm{SO}_{2}$ levels in the PBL tend to be highly variable; however, in general, the cause factors are not well defined amidst the lockdown period. For comparison, the recent studies have investigated the changes of air quality under lockdown condition due to the COVID-19 at different regions of the globe (e.g., Jain and Sharma, 2020; Panda et al., 2020; Sharma et al., 2020; Shen et al., 2020; Sannino et al., 2021; Venkat Ratnam et al., 2021). The results revealed and suggested that meteorology plays a key role in the variation of air pollutant levels on regional and global scales. Further, Putaud et al. (2004) and Jayamurugan et al. (2013) have statistically shown a strong inverse linkage between RH and air pollutant concentration with the emphases that $49.99 \% \mathrm{RH}$ provides the more favorable condition to $\mathrm{PM}_{10}$ lead to a 1.09 times increase, and $20 \%$ RH contribute 1.07 times increase in $\mathrm{PM}_{2.5}$ concentration. Therefore, along with the lockdown, the static meteorological conditions also played a significant role in the decrease of air pollutant levels in most of the places of South Asia including Pakistan, India, and around the world (Jayamurugan et al., 2013; Ahmadi et al., 2020; Gunthe et al., 2020; Shen et al., 2020; Sannino et al., 2021; Venkat Ratnam et al., 2021). 

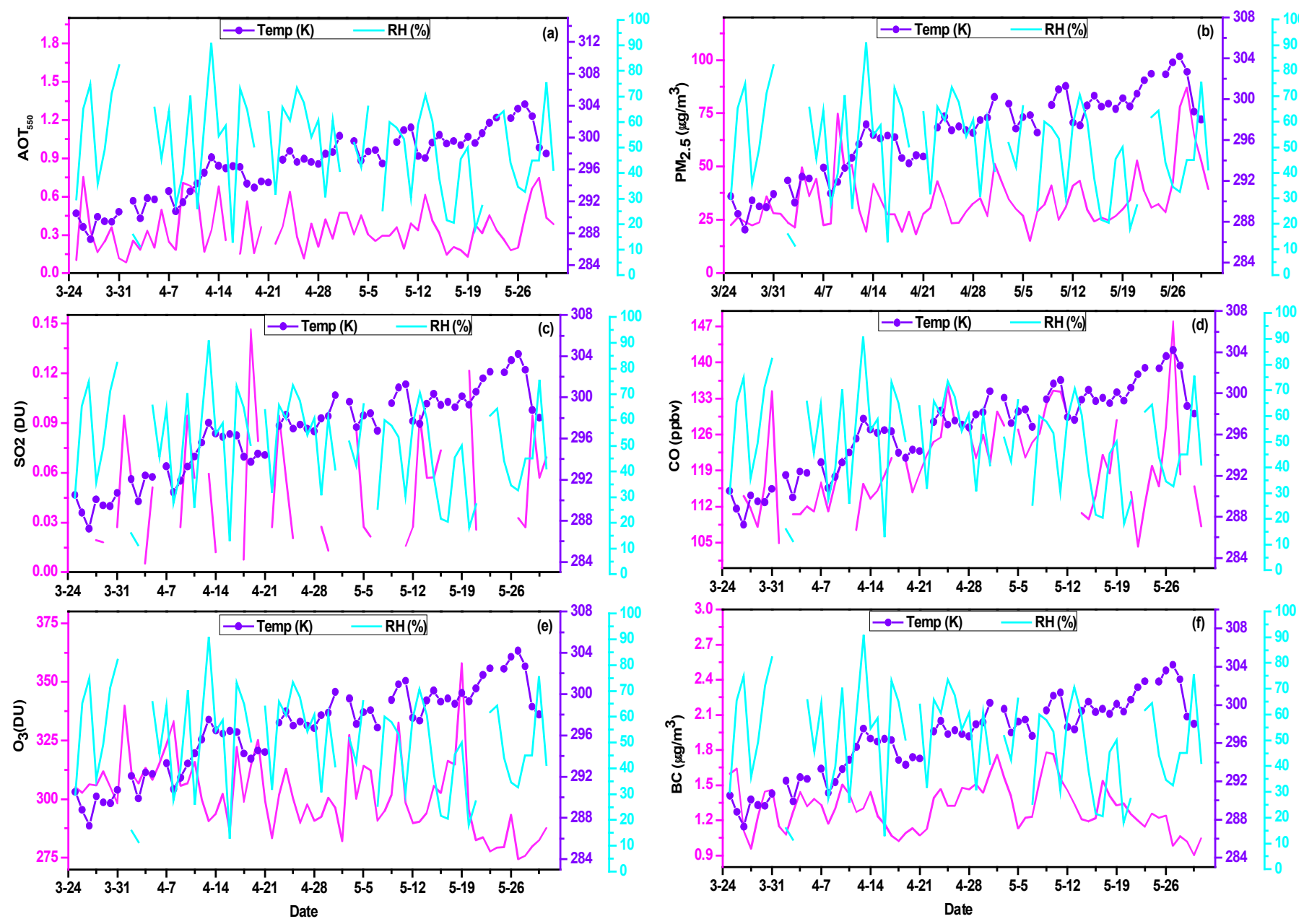

Fig. 6. Same as in Fig. 5, but for the Upper Indus Basin Region.

\section{DISCUSSION}

From the obtained results, we could note that the government has taken initial measures in response to the COVID-19 pandemic that has positively impacted the air quality in different urban and industrial regions of the country. The aerosol ( $\mathrm{AOT}, \mathrm{BC}, \mathrm{PMx})$ and trace gases $\left(\mathrm{NO}_{2}, \mathrm{SO}_{2}, \mathrm{O}_{3}\right.$, CO) concentration were reduced in most of the study domain during the DLP-2020. The IBR and the surrounding regions showed a marginal to lower decrease in the spatial and temporal extent, despite reports of greatly reduced anthropogenic activities (industrial, transportation) during the DLP-2020 period. Besides, the increase in $\mathrm{O}_{3}$ across the country during the lockdown phase observed by Aura-OMI suggests that vehicular and traffic measures may have little effect in controlling regional air pollution. Because the concentration of the studied pollutant was not observed as low as was expecting, which is mainly associated with the domestic activities and the seasonal production of natural dust particles actively visiting the study region every year in summer and early spring. Regional meteorology is also playing an active role in the increase of $\mathrm{O}_{3}$.

Dealing with the impact of COVID-19 pandemic lockdown on air quality, several studies were conducted and published during the last few months, by utilizing the space-borne and groundbased data sets around the globe (e.g., Berman and Ebisu, 2020; Dantas et al., 2020; IQAIR, 2020; Mahato et al., 2020; nCoV-2019 Data Working Group, 2020; Tobías et al., 2020; WHO, 2020a, b) and in Asian continent (e.g., Abdullah et al., 2020; Chen et al., 2020; Li et al., 2020; Muhammad et al., 2020; Sharma et al., 2020; Wang et al., 2020; and references therein). Almost all of these studies showed declining tendencies in trace gases $\left(\mathrm{NO}_{2}, \mathrm{SO}_{2}, \mathrm{O}_{3}, \mathrm{CO}, \mathrm{BC}\right)$, column aerosol loading, and $\mathrm{PM}$ concentrations. The reasons for the considerable decrement in pollutant levels are 

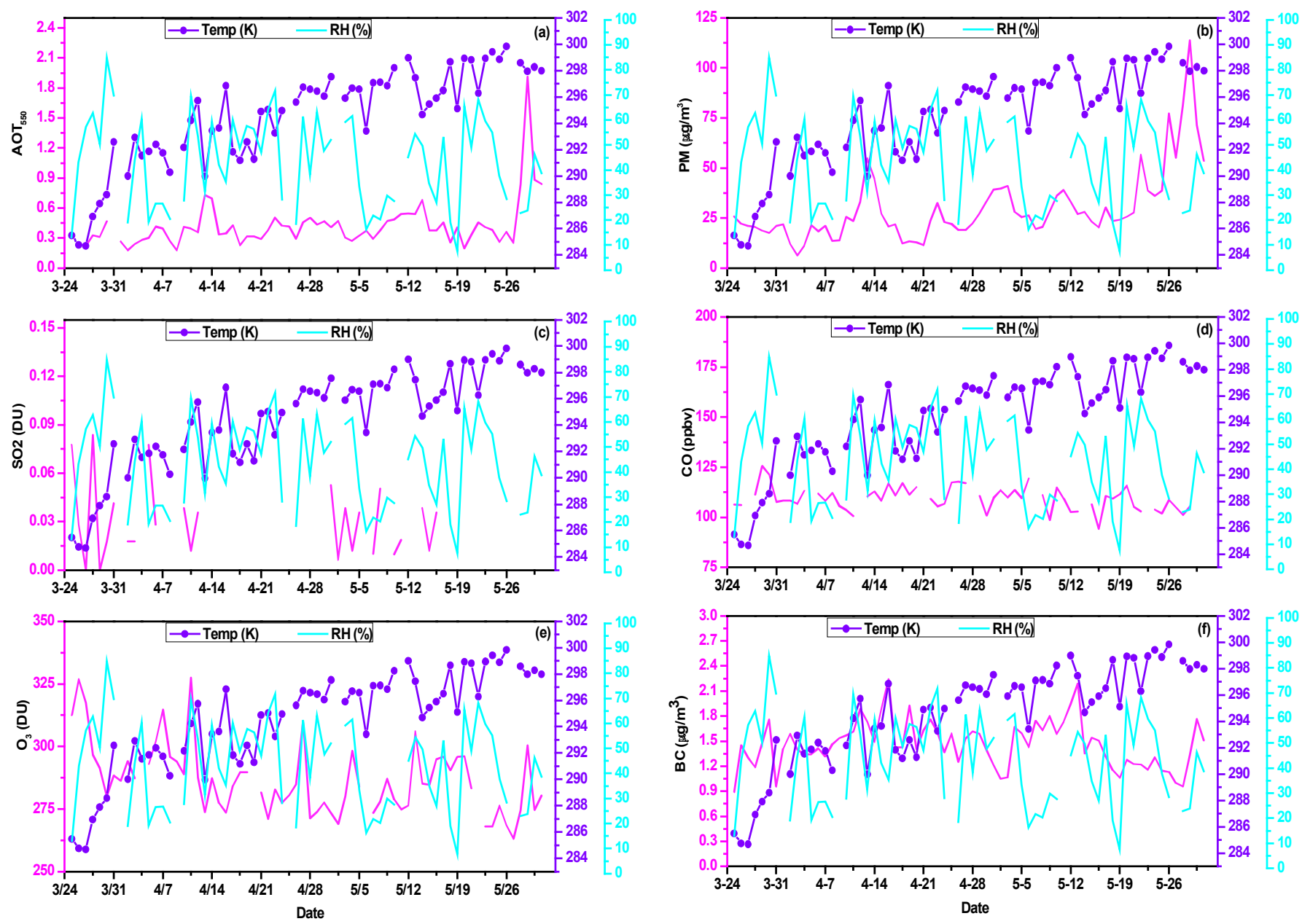

Fig. 7. Same as in Fig. 5, but for the Balochistan Plateau.

related to the specific features of location, relative influence of natural/anthropogenic emission, local/regional meteorology, and the proximity of different energy sectors.

For instance, the Ministry of ecology and environment of China (MEEC, 2020) predicted a gradual decrease in other air pollutants by $-20 \%,-15 \%$, and $-21 \%$ in $\mathrm{PM}_{10}, \mathrm{PM}_{2.5}$, and $\mathrm{SO}_{2}$, respectively (Wang et al., 2020) during the lockdown period of January-February 2020. A large decrease in $\mathrm{BC}(-45.4 \%)$ and $\mathrm{PM}_{10}(-31 \%)$ was observed in the urban regions of Europe such as Barcelona (Spain) (Tobías et al., 2020) and Milan (Italy) (Conticini et al., 2020). This agrees well with the percent decrease of $\mathrm{CO}$ and $\mathrm{BC}$ pollutants over IBR and BP regions in Pakistan. Recent studies have also included the analysis of $\mathrm{O}_{3}$, a highly variable and secondary aerosol species, mainly dependent on the meteorological factor (solar radiation and temperature) and the varying season. The daily $\mathrm{O}_{3}$ levels are significantly increased in New Delhi, India (17\%), North China (14-45\%), Morocco (12-33\%), and Spain (29-58\%), which is far greater than from our results. However, in general, the changes in $\mathrm{O}_{3}$ are mostly associated or linked up with the variations in $\mathrm{NO}_{x}$ (Reddy et al., 2012). Hence, as the $\mathrm{NO}_{2}$ decreases result in an increase of $\mathrm{O}_{3}$ and vice versa (Kerimray et al., 2020). A more detailed analysis and comparison of different studies are given in Table 2.

\section{CONCLUSIONS}

The present study provides a preliminary evaluation of improvements in the regional air quality of Pakistan during the COVID-19 pandemic nationwide lockdown. We observed pronounced changes (in percent) detected by the satellite-derived estimates in surface mass concentrations of $\mathrm{BC}, \mathrm{PM}_{2.5}$, and column $\mathrm{SO}_{2}$ as $-11.39 \%,-19.17 \%$, and $-34 \%$ over the KPK region; $-8.57 \%,-0.26 \%$, 
Table 2. Mean concentrations of $\mathrm{CO}, \mathrm{O}_{3}, \mathrm{SO}_{2}, \mathrm{BC}$, and $\mathrm{PM}_{2.5}$, analyzed for the BLP-2019 and DLP-2020 phases over different regions across the globe. The differences of two different data periods with its percentage values are also presented.

\begin{tabular}{llllll}
\hline Air pollutants & Study Region & BLP-2019 & DLP-2020 & Relative Difference (\%) & Citation \\
\hline $\mathrm{CO}(\mathrm{ppbv})$ & Delhi (India) & 1.03 & 0.72 & -30.35 & Mahato et al. (2020) \\
& Kolkata (India) & 0.6 & 0.5 & -18.18 & Jain and Sharma (2020) \\
& Hubei (China) & 1.207 & 1.02 & -16.79 & Bao and Zhang (2020) \\
& Urban location (Malaysia) & 0.8 & 0.49 & -48.06 & Kanniah et al. (2020) \\
& Chennai (India) & 0.79 & 0.52 & -41.22 & Jain and Sharma (2020) \\
& Delhi (India) & 34.05 & 34.32 & 0.79 & Mahato et al. (2020) \\
$\mathrm{O}_{3}(\mathrm{DU})$ & Bhubaneswar (India) & 34.7 & 22.2 & -36.15 & Panda et al. (2020) \\
& Kolkata (India) & 45.55 & 40.11 & 12.70 & Jain and Sharma (2020) \\
& Wuhan (China) & 35.33 & 79.22 & 76.63 & Lian et al. (2020) \\
& Urban location (Malaysia) & 22 & 23.99 & 8.65 & Kanniah et al. (2020) \\
& Chennai (India) & 44.1 & 45.2 & 2.46 & Jain and Sharma (2020) \\
& Sale (Morocco) & 6.6 & 3.3 & -0.49 & Kanniah et al. (2020) \\
$\mathrm{SO}_{2}(\mathrm{DU})$ & Urban location (Malaysia) & 1.42 & 0.99 & -35.68 & Bao and Zhang (2020) \\
$\mathrm{SO}_{2}\left(\mu \mathrm{g} \mathrm{m}^{-3}\right)$ & Hubei (China) & 15.81 & 13.83 & -13.36 & Panda et al. (2020) \\
$\left.\mathrm{BC}^{-3}(\mu \mathrm{g} \mathrm{m})^{-3}\right)$ & Bhubaneswar (India) & 1.94 & 0.95 & -51.03 & Mahato et al. (2020) \\
$\mathrm{PM}_{2.5}\left(\mu \mathrm{g} \mathrm{m}{ }^{-3}\right)$ & Delhi (India) & 80.51 & 37.75 & -53.11 & Nakada et al. (2020) \\
& Sao Paulo (Brazil) & 12.9 & 12.5 & -3.60 & Jain and Sharma (2020) \\
& Chennai (India) & 29.38 & 27.33 & -7.23 & Bao and Zhang (2020) \\
& Hubei (China) & 81.83 & 65.81 & -21.70 & Lian et al. (2020) \\
& Wuhan (China) & 65.5 & 40.11 & -48.08 & Kanniah et al. (2020) \\
\hline & Urban location (Malaysia) & 32.3 & 22.34 & -36.46 &
\end{tabular}

and $-36.1 \%$ over the BP region, respectively during DLP-2020 and BLP-2019 periods. However, the decline in the levels of $\mathrm{BC}(-22.43 \%), \mathrm{PM}_{2.5}(-0.82 \%)$, and $\mathrm{SO}_{2}(-15.15 \%)$ was found comparatively variant in the region of IBR. Despite, the visible decrease in the air pollutant concentrations, some of them (PM, CO) was found remains less elevated in many regions of Pakistan. As expected, a significant decrease in column aerosol load was observed over KPK, IBR, and BP with a difference (\% variation) of $-0.02(-9.09 \%),-0.02(-4.34 \%)$, and $-0.01(-2.9 \%)$, respectively. Among all pollutants, a slight increase in $\mathrm{O}_{3}$ was found in BP $(5.78 \%)$, IBR $(4.74 \%)$, and KPK $(4.13 \%)$ for the DLP-2020. In summary, a considerable reduction in the pollutant concentrations of AOT, BC, CO, $\mathrm{PM}_{2.5}$, and $\mathrm{SO}_{2}$ over different regions in Pakistan attributed to the implementation of COVID-19 pandemic lockdown. When comparing DLP-2020 to the same period in BLP-2019, we found important differences in surface temperature and $\mathrm{RH}$ that could strongly influence air pollutant levels in Pakistan. It was found that these meteorological factors provided a more favorable environment for the decrease in pollutant concentrations in DLP-2020 compared to BLP-2019. The present work is important and gives confidence to the regulatory bodies to implement mitigation measures in future long-term air quality assessment on a local/regional basis. The same can be achieved through a natural simulation and modeling techniques that will help to bring suitable alternatives for turning down the anthropogenic activities.

\section{ADDITIONAL INFORMATION}

\section{CRediT Author Statement}

All authors have read and agreed to the published version of the manuscript.

Rehana Khan: Data curation, Methodology, Formal analysis, Visualization, Investigation, Writing-Original Draft. Kanike Raghavendra Kumar: Conceptualization, Resources, Supervision, and Writing-review and editing. Tianliang Zhao: Project Administration, Supervision, and Writingreview and editing.

\section{Conflicts of Interest}

The authors declare that they have no competing financial interests or personal relationships 
that could have appeared to influence the work reported in this paper.

\section{Funding Sources}

This research was funded by the Chinese Tibetan Plateau Scientific Expedition and Research (STEP) program (2019QZKK0105), the National Natural Science Foundation of China (Grant No. 42030612), Fund Project of Central Asian Atmospheric Science Research (CAAS201913), and the Start-Up Research Grant (SRG) (File No. SRG/2020/001445) sanctioned by the Science and Engineering Research Board (SERB), a statutory body under the Department of Science and Technology (DST), Govt. of India. One of the authors, KRK, is also grateful to the DST, Govt. of India, for the award of the DST-FIST Level-1 (SR/FST/PS-1/2018/35) scheme to the Department of Physics, KLEF.

\section{Data Availability Statement}

Satellite (AIRS, OMI, and MODIS), and model reanalysis (MERRA-2) datasets are freely accessible to the public from their respective websites https://modis.gsfc.nasa.gov/ and https://gmao.gsfc. nasa.gov/reanalysis/MERRA-2/.

\section{ACKNOWLEDGMENTS}

We sincerely thank the scientific teams of OMI, MODIS, and AIRS sensors for making observations freely available to the public domain through their respective sites. We also owe our gratitude to the GES DISC for the dissemination of MERRA-2 reanalysis model data. The authors would like to acknowledge Prof. Gehui Wang, the Editor-in-Chief of the Journal, and the two anonymous reviewers for their constructive and fruitful comments provided with suggestions that greatly helped us towards the improvement of earlier versions of the manuscript.

\section{REFERENCES}

Abdullah, S., Mansor, A.A., Napi, N.N.L.M., Mansor, W.N.W., Ahmed, A.N., Ismail, M., Ramly, Z.T.A. (2020). Air quality status during 2020 Malaysia Movement Control Order (MCO) due to 2019 novel coronavirus (2019-nCoV) pandemic. Sci. Total Environ. 729, 139022. https://doi.org/10.1016/j.scitotenv.2020.139022

Ahlawat, A., Wiendensohler, A., Mishra, S.K. (2020). An overview on the role of relative humidity in airborne transmission of SARS-CoV-2 in indoor environments. Aerosol Air Qual. Res. 20, 1856-1861. https://doi.org/10.4209/aaqr.2020.06.0302

Ahmadi, M., Sharifi, A., Dorosti, S., Jafarzadeh Ghoushchi, S., Ghanbari, N. (2020). Investigation of effective climatology parameters on COVID-19 outbreak in Iran. Sci. Total Environ. 729, 138705. https://doi.org/10.1016/j.scitotenv.2020.138705

Alam, K., Thomas T., Thomas B., Hussain M. (2012). Aerosol optical and radiative properties during summer and winter seasons over Lahore and Karachi. Atmos. Environ. 50, 234-45. https://doi.org/10.1016/j.atmosenv.2011.12.027

Albrecht, B.A. (1989). Aerosols, cloud microphysics, and fractional cloudiness. Science. 245, 1227-1230. https://doi.org/10.1126/science.245.4923.1227

Aumann, H.H., Chahine, M.T., Gautier, C., Goldberg, M.D., Kalnay, E., McMillin, L.M., Revercomb, H., Rosenkranz, P.W., Smith, W.L., Staelin, D.H., Strow, L.L., Susskind, J. (2003). AIRS/AMSU/HSB on the Aqua mission: Design, science objectives, data products, and processing systems. IEEE Trans. Geosci. Remote Sens. 41, 253-264. https://doi:10.1109/TGRS.2002.808356

Bao, R., Zhang, A. (2020). Does lockdown reduce air pollution? Evidence from 44 cities in northern China. Sci. Total Environ. 731, 139052. https://doi.org/10.1016/j.scitotenv.2020.139052

Bauwens, M., Compernolle, S., Stavrakou, T., Müller, J.F., van Gent, J., Eskes, H., Levelt, P.F., der A, R.V., Veefkind, J.P., Vlietinck, J., Yu, H., Zehner, C. (2020). Impact of coronavirus outbreak on $\mathrm{NO}_{2}$ pollution assessed using TROPOMI and OMI observations. Geophys. Res. Lett. 47, 32836515. https://doi.org/10.1029/2020GL087978

Berman, J.D., Ebisu, K. (2020). Changes in U.S. air pollution during the COVID-19 pandemic. Sci. 
Total Environ. 739, 139864. https://doi.org/10.1016/j.scitotenv.2020.139864

Bowman, F.M., Sheehan, P.E. (2001). Estimated effects of temperature on secondary organic aerosol concentrations. Environ. Sci. Technol. 36, 2701-2707. https://doi.org/10.1021/es015717g

Broomandi, P., Karaca, F., Nikfal, A., Jahanbakhshi, A., Tamjidi, M., Kim, J.R. (2020). Impact of COVID-19 event on the air quality in Iran. Aerosol Air Qual. Res. 20, 1793-1804. https://doi.org/10.4209/aaqr.2020.05.0205

Buchard, V., Randles, C., Da Silva, A., Darmenov, A., Colarco, P., Govindaraju, R., Ferrare, R., Hair, J., Beyersdorf, A., Ziemba, L. (2017). The MERRA-2 aerosol reanalysis, 1980 onward. Part II: Evaluation and case studies. J. Clim. 30, 6851-6872. https://www.jstor.org/stable/26388569

Carrico, C.M., Kus, P., Rood, M.J., Quinn, P.K., Bates, T.S. (2003). Mixtures of pollution, dust, sea salt, and volcanic aerosol during ace-Asia: Radiative properties as a function of relative humidity J. Geophys. Res. 108, 8650. https://doi.org/10.1029/2003JD003405

Centers for Disease Control and Prevention (CDC) (2020). First Travel-Related Case of 2019 Novel Coronavirus Detected in United States. https://www.cdc.gov/media/releases/2020/p0121novel-coronavirus-travel-case.html

Chahine, M., Barnet, C., Olsen, E.T., Chen, L., Maddy, E. (2005). On the determination of atmospheric minor gases by the method of vanishing partial derivatives with application to CO 2 . Geophys. Res. Lett. 32, L22803. https://doi.org/10.1029/2005GL024165

Chauhan, A., Singh, R.P. (2020). A decline in $\mathrm{PM}_{2.5}$ concentrations over major cities around the world associated with COVID-19. Environ. Res. 187, 109634. https://doi.org/10.1016/j.envres. 2020.109634

Chen, K., Wang, M., Huang, C., Kinne y, P.L., Anastas, P.T. (2020). Air pollution reduction and mortality benefit during the COVID-19 outbreak in China. Lancet Planet. Health 4, 210-212. https://doi.org/10.1016/S2542-5196(20)30107-8

Conticini, E., Frediani, B., Caro, D. (2020). Can atmospheric pollution be considered a cofactor in extremely high level of SARS-CoV-2 lethality in northern Italy? Environ. Pollut. 261, 114465. https://doi.org/10.1016/j.envpol.2020.114465

Dantas, G., Siciliano, B., BoscaroFrança, B., Da Silva, C.M., Arbilla, G. (2020). The impact of COVID19 partial lockdown on the air quality of the city of Rio de Janeiro, Brazil. Sci. Total Environ. 729, 139085. https://doi.org/10.1016/j.scitotenv.2020.139085

Faridi, S., Yousefian, F., Niazi, S., Ghalhari, M.R., Hassanvand, M.S., Naddafi. K. (2020). Impact of SARS-CoV-2 on ambient air particulate matter in Tehran. Aerosol Air Qual. Res. 20, 1805-1811. https://doi.org/10.4209/aaqr.2020.05.0225

Gelaro, R., McCarty, W., Suárez, M.J., Todling, R., Molod, A., Takacs, L., Randles, C.A., Darmenov, A., Bosilovich, M.G., Reichle, R., Wargan, K. (2017). The Modern-Era Retrospective analysis for Research and Applications, Version 2 (MERRA-2). J. Clim. 30, 5419-5454. https://doi.org/10.1 175/JCLI-D-16-0758.1

Gunthe, S.S., Swain, B., Patra, S.S., Amte, A. (2020). On the global trends and spread of the COVID19 outbreak: Preliminary assessment of the potential relation between location-specific temperature and UV index. J. Public Health https://doi.org/10.1007/s10389-020-01279-y

Hsu, N.C., Tsay, S.C., King, M.D., Herman, J.R. (2004). Aerosol properties over bright-reflecting source regions. IEEE Trans. Geosci. Remote Sens. 42, 557-569. https://doi.org/10.1109/TGRS. 2004.824067

IQAir (2020). REPORT: COVID-19 impact on air quality in 10 major cities. IQAir https://www.iqair.C om/blog/air-quality/report-impact-of-covid-19-on-global-air-quality-earth-day

Jahangiri, M., Jahangiri, M., Najafgholipour, M. (2020). The sensitivity and specificity analyses of ambient temperature and population size on the transmission rate of the novel coronavirus (COVID-19) in different provinces of Iran. Sci. Total Environ. 728, 138872. https://doi.org/10.10 16/j.scitotenv.2020.138872

Jain, S., Sharma, T. (2020). Social and travel lockdown impact considering coronavirus disease (COVID-19) on air quality in megacities of India: Present benefits, future challenges and way forward. Aerosol Air Qual. Res. 20, 1222-1236. https://doi.org/10.4209/aaqr.2020.04.0171

Jayamurugan, R., Kumaravel, B., Palanivelraja, S., Chockalingam, M.P. (2013). Influence of temperature, relative humidity and seasonal variability on ambient air quality in a coastal urban area. Int. J. Atmos. Sci. 2013, 264046. https://doi.org/10.1155/2013/264046

Kanniah, K.D., Zaman, N.A.F.K., Kaskaoutis, D.g., Latif, M.T. (2020). COVID-19's impact on the 
atmospheric environment in the Southeast Asia region. Sci. Total. Environ. 736, 139658. https://doi.org/10.1016/j.scitotenv.2020.139658 0048-96

Kaufman, Y.J., Tanr, D., Remer, L.A., Vermote, E.F., Chu, A. (1997). Operational remote sensing of tropospheric aerosol over land from EOS moderate resolution imaging spectroradiometer. J. Geophys. Res. 102, 51-67. https://doi.org/10.1029/96JD03988

Kerimray, A., Baimatova, N., Ibragimova, O.P., Bukenov, B., Kenessov, B., Plotitsyn, P., Karaca, F. (2020). Assessing air quality changes in large cities during COVID-19 lockdowns: The impacts of traffic-free urban conditions in Almaty, Kazakhstan. Sci. Total Environ. 730, 139179. https://doi.org/10.1016/j.scitotenv.2020.139179

Khan, R., Kumar, K.R., Zhao, T. (2019). The climatology of aerosol optical thickness and radiative effects in Southeast Asia from 18-years of ground-based observations. Environ. Pollut. 254, 113025. https://doi.org/10.1016/j.envpol.2019.113025

Khan, R., Kumar, K.R., Zhao, T. (2020). The contribution of different aerosol types to direct radiative forcing over distinct environments of Pakistan inferred from the AERONET data. Environ. Res. Lett. 15, 114062. https://doi.org/10.1088/1748-9326/aba2a6

Kumar, K.R., Sivakumar, V., Reddy, R.R., Gopal, K.R. (2013). Ship-borne measurements of columnar and surface aerosol loading over the bay of Bengal during W-ICARB campaign: Role of air mass transport, latitudinal and longitudinal gradients. Aerosol Air Qual. Res. 13, 818-837. https://doi.org/10.4209/aaqr.2012.08.0225

Lelieveld, J., Heintzenberg, J. (1992). Sulfate cooling effects on climate through in-cloud oxidation of anthropogenic $\mathrm{SO}_{2} .258,117-120$. https://doi.org/10.1126/science.258.5079.117

Levelt, P.F., Hilsenrath, E., Leppelmeier, G.W., van den Oord, G.H.J., Bhartia, P.K., Taminnen, J., de Haan, J.F., Veefkind J.P. (2006). Science objectives of the ozone monitoring instrument. IEEE Trans. Geosci. Remote Sens. 44, 1093-1101. https://doi.org/10.1109/TGRS.2006.872336

Levy, R.C., Matto, S., Munchak, L.A., Remer, L.A., Sayer, A.M., Patadia, F., Hsu, N.C. (2013). The Collection 6 MODIS aerosol products over land and ocean. Atmos. Meas. Tech. 6, 2989-3034. https://doi.org/10.5194/amt-6-2989-2013

Li, L., Li, Q., Ling, H., Wang, Q., Zhu, A., Xu, J., Liu, Z., Li, H., Shi, L., Li, R., Azari, M., Wang, Y., Zhang, X., Liu, Z., Zhu, Y., Zhang, K., Xue, S., Ooi, M.C.G., Zhang, D., Chan, A. (2020). Air quality changes during the COVID-19 lockdown over the Yangtze River Delta region: An insight into the impact of human activity pattern changes on air pollution variation. Sci. Total. Environ. 732, 139282. https://doi.org/10.1016/j.scitotenv.2020.139282

Lian, X., Huang, J., Huang, R. Liu, C., Wang, L., Zhang, T. (2020). Impact of city lockdown on the air quality of COVID-19-hit of Wuhan city. Sci. Total Environ. 742, 140556. https://doi.org/10.1016/ j.scitotenv.2020.140556

Ma, J., Xu, J., Qu, Y. (2020a). Evaluation on the surface PM2.5 concentration over China mainland from NASA's MERRA-2. Atmos. Environ. 237, 117-666. https://doi.org/10.1016/j.atmosenv.20 20.117666

Ma, Y., Zhao, Y., Liu, J., He, X., Bo, W., Fu, S., Yan, J., Niu, J., Zhou, J., Luo, B. (2020b). Effects of temperature variation and humidity on the death of COVID-19 in Wuhan, China. Sci. Total Environ. 724, 138226. https://doi.org/10.1016/j.scitotenv.2020.138226

Mahato, S., Pal, S., Ghosh, K.G. (2020). Effect of lockdown amid COVID-19 pandemic on air quality of the megacity Delhi, India. Sci. Total. Environ. 730, 139086. https://doi.org/10.1016/j.scitote nv.2020.139086

Martínez, L.D.L., Vega, L.S., Ramirez, A.P., Aguilar, M.R., Ramirez, R.F. (2020). Critical review of social, environmental and health risk factors in the Mexican indigenous population and their capacity to respond to the COVID-19. Sci. Total Environ. 733, 139357. https://doi.org/10.1016/ j.scitotenv.2020.139357

Mayol-Bracero, O.L., Gabriel, R., Andreae, M.O. (2002). Carbonaceous aerosols over the Indian Ocean during the Indian Ocean Experiment (INDOEX): Chemical characterization, optical properties, and probable sources. J. Geophys. Res. 107, 8030. https://doi.org/10.1029/2000JD 000039

Ministry of Ecology and Environment of China (MEEC) (2020). Report on the state of surface water and ambient air quality nationwide in March and January-March. http://www.mee.gov. cn/xxgk2018/xxgk/xxgk15/202004/t20200414_774254.html

Muhammad, S., Long, X., Salman, M. (2020). COVID-19 pandemic and environmental pollution: 
A blessing in disguise? Sci. Total Environ. 728, 138820. https://doi.org/10.1016/j.scitotenv.202 0.138820

Nakada, L.Y.K., Urban, R.C. (2020). COVID-19 pandemic: Impacts on the air quality during the partial lockdown in São Paulo state, Brazil. Sci. Total Environ. 730, 139087. https://doi.org/10. 1016/j.scitotenv.2020.139087

National Aeronautics and Space Administration (NASA) (2020). Airborne Nitrogen Dioxide Plummets over China. https://earthobservatory.nasa.gov/images/146362/airborne-nitrogendioxide-plummets-over-china

nCoV-2019 Data Working Group (2020) Epidemiological data from the nCoV-2019 outbreak: Early descriptions from publicly available data. http://virological.org/t/epidemiological-data-fromthe-ncov-2019-outbreak-early-descriptions-from publicly-available-data/337

Otmani, A., Benchrif, A., Tahri, M., Bounakhla, M., Chakir, E.M., Bouch, M.E., Krombi, M. (2020). Impact of Covid-19 on $\mathrm{PM}_{10}, \mathrm{SO}_{2}$, and $\mathrm{NO}_{2}$ concentrations in Sale City (Morocco). Sci. Total Environ.735, 139541. https://doi.org/10.1016/j.scitotenv.2020.139541

Panda, S., Mallik, C., Nath, J., Das, T., Ramasamy, B. (2020). A study on variation of atmospheric pollutants over Bhubaneswar during imposition of nationwide lockdown in India for the COVID-19 pandemic. 2020. Air Qual. Atmos. Health 14, 97-108. https://doi.org/10.1007/s118 69-020-00916-5

Putaud, J.P., Raes, F., Van Dingenen, R., Brüggemann, E., Facchini, M.C., Decesari, S., Fuzzi, S., Gehrig, R., Hüglin, C., Laj, P., Lorbeer, G., Maenhaut, W., Mihalopoulos, N., Müller, K., Querol, X., Rodriguez, S., Schneider, J., Spindler, G., ten Brink, H., ..., Wiedensohler, A. (2004). A European aerosol phenomenology-2: chemical characteristics of particulate matter at kerbside, urban, rural and background sites in Europe. Atmos. Environ. 38, 2579-2595. https://doi.org/ 10.1016/j.atmosenv.2004.01.041

Randles, C.A., da Silva, A.M., Buchard, V., Colarco, P.R., Darmenov, A., Govindaraju, R., Smirnov, A., Holben, B., Ferrare, R., Hair, J., Shinozuka, Y., Flynn, C.J. (2017). The MERRA-2 aerosol reanalysis, 1980 onward. Part I: System description and data assimilation evaluation. J. Clim. 30, 6823-6850. https://doi.org/10.1175/JCLI-D-16-0609.1

Reddy, B.S.K., Kumar, K.R., Balakrishnaiah, G., Gopal, K.R., Reddy, R., Sivakumar, V., Lingaswamy, A., Arafath, S., Umadevi, K., Kumari, S.P., Ahammed, Y.N., Lal, S. (2012). Analysis of diurnal and seasonal behavior of surface ozone and its precursors $\left(\mathrm{NO}_{\mathrm{x}}\right)$ at a semi-arid rural site in southern India. Aerosol Air Qual. Res. 12, 1081-1094. https://doi.org/10.4209/aaqr.2012.03.0055

Remer, L.A., Kaufman, Y. J., Tanre, D., Mattoo, S., Chu, D.A., Martins, J.V., Li, R.R., Ichoku, C., Levy, R.C., Kleidman, R.G., Eck, T.F., Vermote, E.F., Holben, B.N. (2005). The MODIS aerosol algorithm, products and validation; J. Atmos. Sci. 62, 947-973. https://doi.org/10.1175/JAS3385.1

Sannino, A., D’Emilio, M., Castellano, P., Amoruso, S., Boselli, A. (2021). Analysis of air quality during the COVID-19 pandemic lockdown in Naples (Italy). Aerosol Air Qual. Res. 21, 200381. https://doi.org/10.4209/aaqr.2020.07.0381

Sayer, A.M., Hsu, N.C., Bettenhausen, C., Jeong, M.J. (2013). Validation and uncertainty estimates for MODIS Collection 6 "Deep Blue" aerosol data. J. Geophys. Res. 118, 864-7872. https://doi.org/10.1002/jgrd.50600

Sharma, S., Zhang, M., Anshika, Gao, J., Zhang, H., Kota, S.H. (2020). Effect of restricted emissions during COVID-19 on air quality in India. Sci. Total Environ. 728, 138878. https://doi.org/10.101 6/j.scitotenv.2020.138878

Shen, L., Zhao, T., Wang, H., Liu, J., Bai, Y., Kong, S., Zheng, H., Zhu, Y., Shu, Z. (2020). Importance of meteorology in air pollution events during the city lockdown for COVID-19 in Hubei province, Central China. Sci. Total Environ. 754, 142227. https://doi.org/10.1016/j.scitotenv.2020.142227

Siciliano, B., Carvalho, G., da Silva, C.M., Arbilla, G. (2020). The impact of COVID-19 partial lockdown on primary pollutant concentrations in the atmosphere of Rio de Janeiro and São Paulo megacities (Brazil). Bull. Environ. Contam. Toxicol. 105, 2-8. https://doi.org/10.1007/s0 0128-020-02907-9

Theys, N., de Smedt, I., van Gent, J., Danckaert, T., Wang, T., Hendrick, F., Stavrakou, T., Bauduin, S., Clarisse, L., Li, C., Krotkov, N., Yu, H., Brenot, H., van Roozendael, M. (2015). Sulfur dioxide vertical column DOAS retrievals from the Ozone Monitoring Instrument: Global observations and comparison to ground-based and satellite data. J. Geophys. Res. 120, 2470-2491. https://doi.org/10.1002/2014JD022657 
Tobías, A., Carnerero, C., Reche, C., Massagué, J., Via, M., Minguillón, M.C., Alastuey, A., Querol, $X$. (2020). Changes in air quality during the lockdown in Barcelona (Spain) one month into the SARS-CoV-2 epidemic. Sci Total Environ. 726, 138540. https://doi.org/10.1016/j.scitotenv.202 0.138540

Torres, O., Bhartia, P.K., Herman, J.R., Ahmad, Z., Gleason, J. (1998). Derivation of aerosol properties from satellite measurements of backscattered ultraviolet radiation: Theoretical basis. J. Geophys. Res. 103, 17099-17110. https://doi.org/10.1029/98JD00900

Venkat Ratnam, M., Prasad, P., Akhil, Raj, S.T., Hoteit, I. (2021). Effect of lockdown due to COVID19 on the aerosol and trace gases spatial distribution over India and adjoining regions. Aerosol Air Qual. Res. 21, 200397. https://doi.org/10.4209/aaqr.2020.07.0397

Wang, Y., Yuan, Y., Wang, Q., Liu, C., Zhi, Q., Cao, J. (2020). Changes in air quality related to the control of coronavirus in China: Implications for traffic and industrial emissions. Sci. Total Environ. 731, 139133. https://doi.org/10.1016/j.scitotenv.2020.139133

World Health Organization (WHO) (2020a) Novel Coronavirus-China. https://who.int/csr/don/12-january-2020-novel-coronavirus-china/en/

World Health Organization (WHO) (2020b). Report of the WHO-China Joint Mission on Corona virus Disease 2019 (COVID-19). 16-24 February 2020. World Health Organization. https://www.who.int/docs/default-source/coronaviruse/who-china-joint-mission-on-covid19-final-report.pdf

Xu, Z., Shi, L., Wang, Y., Zhang, J., Huang, L., Zhang, C., Liu, S., Zhao, P., Liu, H., Zhu, L., Tai, Y., Bai, C., Gao, T., Song, J., Xia, P., Dong, J., Zhao, J., Wang, F.S. (2020). Pathological findings of COVID19 associated with acute respiratory distress syndrome. Lancet Respir. Med. 8, 420-422. https://doi.org/10.1016/S2213-2600(20)30076-X

Yurganov, L.N., McMillan, W.W., Dzhola, A.V., Grechko, E.I., Jones, N.B., van der Werf, G.R. (2008). Global AIRS and MOPITT CO measurements: Validation, comparison, and links to biomass burning variations and carbon cycle. J. Geophys. Res., 113, D09301.https://doi.org/10.1029/2 007JD009229

Zhang, M., Su, B., Bilal, M., Atique, L., Usman, M., Qiu, Z., Ali, M.A., Han, H. (2020). An investigation of vertically distributed aerosol optical properties over pakistan using CALIPSO satellite data. Remote Sens. 12, 14. https://doi.org/10.3390/rs12142183

Ziemke, J.R., Chandra, S., Duncan, B.N., Schoeberl, M.R., Torres, O., Damon, M.R., Bhartia, P.K. (2009). Recent biomass burning in the tropics and related changes in tropospheric ozone. Geophys. Res. Lett. 36, 15819. https://doi.org/10.1016/10.1029/2009GL039303 